\title{
Community Democratization Of Telecommunications Community Cooperatives In Argentina: The Case Of Telpin ${ }^{1}$
}

\author{
Susana Finquelievich \\ LINKS, Civil Association for the Development of Information Society $<$ sfinquel@,ciudad.com.ar $>$ \\ Graciela Kisilevsky \\ University of Buenos Aires < gkisi@,ciudad.com.ar >
}

\begin{abstract}
A telecommunications community cooperative (TCC) is an autonomous association of individuals, who join forces to respond to common economic, social, and cultural needs and aspirations through a jointly owned enterprise, democratically governed and managed. In Argentina, TCCs were created by community-conscious members to fill in for the State when it was the State was unable to provide telephone service in remote areas. In 1989, the State telephone enterprise was privatized. From 1992 onwards, TCCs replaced the large private telephone enterprises in remote or low-populated areas, since these were not interested in providing services which would not be profitable.

TCCs provide telephone and Internet service, through dial-up and/or broadband (ADSL) connections, as well as Internet Protocol (IP) telephony, to their target populations at significantly lower costs than the large traditional firms (Telefónica and Telecom). Most TCCs also offer free community services, such as courses on information and communication technologies (ICTs), and free Internet access to public schools, libraries, and public facilities (police stations, hospitals, etc.).

This study focuses on a particular case, TELPIN, the Pinamar Telecommunications Cooperative. Telpin was created in 1962 by a group of Pinamar neighbors. Since then, it has become the largest and most successful Telecommunications Cooperative in Argentina.
\end{abstract}

\section{Resumen}

Una cooperativa comunitaria de telecomunicaciones (CCT o, en inglés, TCC) es una asociación autónoma de individuos, los cuales unen sus fuerzas para solucionar un problema social o económico común, así como las necesidades y aspiraciones culturales de la comunidad, por medio de una empresa de propiedad en común, democráticamente gobernada y administrada. En La Argentina, las CCTs fueron creadas por los miembros de la comunidad para suplir el rol del Estado o de las empresas privadas, cuando éstas no proporcionaban servicio telefónico en áreas alejadas, marginado a la población de los servicios de comunicaciones. En 1989, la empresa de teléfonos del Estado, ENTEL, fue privatizada. Desde 1992 hacia adelante, las CCTs substituyeron a las grandes

1 This paper is based on a case study developed by Susana Finquelievich and Graciela Kisilevsky for "Comunica.org”, coordinated by Bruce Girard, and funded by UNDP, 2004. 
empresas privadas de telecomunicaciones, puesto que éstas no estaban interesadas en el abastecimiento de servicios no rentables en áreas remotas o de baja densidad poblacional. Las CCTs proporcionan actualmente las conexiones telefónicas y servicios del Internet, por terminal de marcado manual y/o conexiones de banda ancha (ADSL), así como la telefonía del IP, a sus poblaciones, a costos perceptiblemente más bajos que las firmas tradicionales (Telefónica y France Telecom). La mayoría de ellos ofrece también servicios comunitarios, como cursos sobre tecnologías de información y de comunicación (TICS), acceso libre y gratuito a Internet a las escuelas públicas, bibliotecas, e instituciones públicas (comisarias de policias, hospitales, etc.). Este trabajo se centra en un estudio de un caso particular: TELPIN, la cooperativa de telecomunicaciones e Internet de Pinamar. Telpin fue creado por un grupo de los vecinos de Pinamar, la mayoría de ellos fundadores de la comunidad local, en 1962. Desde entonces, se ha convertido en la cooperativa de telecomunicaciones más exitosa de la Argentina.

\section{TELECOMMUNICATIONS COMMUNITY COOPERATIVES: CIVIL SOCIETY'S INTEGRATION INTO THE NEW ECONOMY?}

In the 1990s, the transformations that took place in the world economy - focused mainly on information and communication technology (ICT) were described as the New Economy (NE). "If the eighteenth and nineteenth centuries marked the passage from agricultural economy to the industrial economy, and most of the twentieth century witnessed the change from an industry-based economy to a services-based economy, the last decade of the twentieth century signaled the change to a weightless economy, the knowledge economy" (Stiglitz, 2003, p. 228). Many developed countries, and a few emerging ones, have espoused national strategies intended to amplify the innovative power of their industries.

Castells (2000), summarized by Obendorf (2000), states that the New Economy is not based just on knowledge. It has three key features, all of which are based in micro-technology:

- Information productivity, based on ICTs

- Real-time; global connectivity of capital flows, productivity, and management, which is based on the technology infrastructure (the Internet).

- Networking, based on the Internet, as the basis for social and economic organization.

Is Civil Society prepared to be a proactive agent in this process? This will depend in large measure on the e-readiness of citizens. Citizen e-readiness describes the readiness of a nation's citizens to participate as proactive agents in the different sectors and levels of the New Economy, and to capitalize on the opportunities to participate offered by the new economic and technological environment (IAP, 2000). It covers many facets in such use, but particularly equality in access opportunities, training, knowledge, and social appropriation of ICTs. In the specific case of the New Economy (NE) environment, citizen ereadiness also defines the ability of individuals, communities, and civil society to participate as proactive agents in the different sectors and levels of the New Economy.

Community engagement is also necessary for citizens' e-readiness, whether it precedes or follows the implementation of technological innovations within the community. As Ramirez et al (2002) express it: "community engagement is more than just holding a public meeting. It is an ongoing interactive process characterized by commitment to ever-changing community needs and interests. The outcomes of community engagement are sometimes surprising, since by bringing together community members for a common purpose - people and organizations who are not in the habit of working together - new relationships are formed within the community, as community members learn how to collaborate. The legacy of the community engagement becomes more than the installation and application of information and communication technologies (ICTs)" (p.2).

One of our main hypotheses is that TCCs are a way for Civil Society organizations to prepare communities for their new roles, and to participate in the construction of a new economy, based -among other factors--on fast and low-cost access to Internet connections, training on ICTs uses, capacities to implement the democratic appropriation of ICT infrastructures, alertness to identify the places of opportunity existing in the NE, and mainly, effective use of ICTs. 


\section{TCCS IN ARGENTINA: THE BACKGROUND}

A telecommunications community cooperative (TCC) is an autonomous association of individuals, who join forces to respond to common economic, social, and cultural needs and aspirations through a jointly owned enterprise, democratically governed and managed. In Argentina, TCCs were created by community conscious members to fill in for the State when the State was unable to provide telephone service in remote areas, generally marginalized in relation to service provision. These cooperatives grew and introduced technological innovations to supply their associates with new services at affordable costs. In 1989, ENTel, the State telephone enterprise was privatized. From 1992 onwards, TCCs replaced the large private telephone enterprises, since these were not interested in providing non-profitable services in remote or low-income areas.

In Argentina, there are two main Cooperative Federations: FECOTEL (which unites 250 cooperatives), and FECOSUR. Among the two, they include 350 telecommunications cooperatives. The largest Cooperative Federation, FECOTEL, is 40 years old. It has more than 5,000 local cooperatives as associates, and manages (among the member cooperatives) more than $\$ 10,000$ million pesos (around $\$ 3,000$ million USD). The cooperative sector serves more than 2. 5 million Argentines, approximately $8 \%$ of the country's population, with 600,000 telephone lines. It invoices 300 million Pesos (around 100 million USD) per year, and employs 3,500 individuals.

\section{Legal Status}

In the 1960s and until the privatization of public enterprises in 1989, telephone services in Argentina were a monopoly managed by ENTel, the State Telephone enterprise, which serviced urban areas, and avoided the complexities of servicing sparsely-populated rural areas. A special regulation that allowed for the creation of Telephone Cooperatives ${ }^{2}$, gave them the right to authorize the provision of telephone services in their areas, if these areas were declared by ENTel as non-profitable. The first cooperative was born in San Genaro, Santa Fe, in 1959. In 1960, a State Decree authorized ENTel to build telephone exchanges for cooperatives, as the latter required. The Cooperatives retained these privileges when ENTel was finally privatized.

The Federation of Telecommunications Cooperatives in the Argentine Republic (Federación de Cooperativas de Telecomunicaciones de la República Argentina limitada, FECOTEL), one of the two main Federations, along with FECOSUR, operates in the whole National territory. It is registered in the National Registry of Cooperatives under the (law) $\mathrm{N}^{\circ}$ 6565. It brings together telecommunications cooperatives providing telecommunication services, data, radio and/or TV transmission, along with other means of communication, whatever the particular technology employed, within or outside the national territory. These cooperatives are controlled by FECOTEL's statute, and by the National laws governing cooperatives.

The national public telephone service is supplied by TECOOP, a national enterprise belonging to the Argentine cooperative movement, created by FECOTEL, and integrated with other Federations and cooperatives. Initially, TECOOP's activities were the implementation and operation of public telephones (either in street booths or in cafés, among other places). Since 1999 it has installed 400.000 lines, with a significant rate of growth. It has also obtained Licenses for Basic National and International Telephony. Cooperatives provide long-distance call services though a prepaid card, developed through an agreement signed by TECOOP and FECOTEL with Telecom.

The cooperative's legal status is defined in the Commerce Code, and regulated by Law $\mathrm{N}^{\circ} 20.337 .{ }^{3}$ This Law defines the cooperative's role as social economy enterprises, which differentiates them from traditional, market-oriented enterprises. The Cooperatives, as members of a Cooperatives Federation, FECOTEL $^{4}$, have also signed a Collective Work Agreement (Convenio Colectivo de Trabajo), which establishes a balance between the rights and dignity of workers and the CCs economic reality. Cooperatives

2 Cooperatives are not necessarily non-profit organizations. What they do is to redistribute their profits among members and associates.

3 See Convenio Colectivo de Trabajo 296/97, http://www.foetrabsas.org/cct29697\%20cooperativas\%20telef.doc

4 http://www.fecoteldatos.com.ar/ 
that were created before 1990 can keep $78 \%$ of their profits, while they must pay $22 \%$ of their interconnection fees as a "toll" to the telephone enterprise that provides the network. However, cooperatives created after the privatization must negotiate the commission to be paid with the telephone enterprises. The terms of the negotiations vary from one cooperative — or Federation — to another.

\section{The Funding Issue}

Cooperatives' main investment sources come from their associates or shareholders, including local enterprises, and from National or provincial Banks loans.

The Banco Nación (National Bank), as well as the Provinces Banks are good funding sources. Any bank would be keen to support cooperatives if these have enough community, political and technological support. Alas, in many cases, the cooperatives' balance sheets are so terrible that they cannot get approval in the technical evaluations for the credits they ask for. Banks should evaluate TCCs, not based on their balance sheets, but on how they have improved their work, on their actions, and on a good investments control. (Source: Interview with Eng. Ricardo Bacalor, MICROTROL Director, provider for cooperatives, October 2004. The translation is ours).

However, opinions on this point are divided. TELPIN's Manager in 2004, Eng. Juan Santoianni, states that cooperatives depend mainly on their associates and on their capacity for self-sustainability:

It's difficult to have access to reasonable credits: banks always grant cooperatives soft credits, social credits, so these loans pass as philanthropic loans to support good works in the community. Of course, some cooperatives must be helped, but this should not be mixed with the enterprises efficiency, nor with the concept of social engagement which is at the base of the cooperatives work. (...) If we work efficiently, if we provide the best and least costly service we can, with the best relatioship cost-services, have reinvestments. We have correct financial balances, and we are audited each three months by an international consultant, but even so we cannot depend on bank credits.

One of the problems affecting cooperatives is their fiscal (tax) status. The military dictatorship (19761983) was opposed to community cooperatives; one of the ways to fight them was to diminish their tax benefits. At present, this reduction in fiscal advantages has not been modified; this is an important claim from the cooperative movement. Cooperative leaders maintain that cooperatives should be legally considered as not subject to gain taxes, since the benefits obtained in their activities must be used for capitalization, or in providing their associates with new or better services.

\section{Ethical conduct: an essential issue}

FECOTEL (2004) is unyielding concerning the cooperatives' ethical behavior. Its associates must "always and in all their actions, respect cooperative principles: open and voluntary membership; democratic control of the organization by its members; economic participation by its members; autonomy and independence; education, continuing training, and information; cooperation between cooperatives; and engagement with the community."

Associate cooperatives are to work in defense of the cooperative movement, and particularly, of the telecommunications cooperative movement, represented by FECOTEL; Cooperatives must observe cooperative values, based on mutual help, responsibility, democracy, equality, equity, solidarity, and respect for federative autonomy. They must not act in the pursuit of hegemonic or dominant positions. Cooperatives associated to FECOTEL are expected to promote agreements between each other, aiming at the construction of cooperative networks, in order to improve and/or incorporate new services, while working towards the implementation of universal service. They must also promote cooperative practice, in order to achieve the best services at the lowest possible prices, avoiding unnecessary intermediations, and searching to incorporate the highest possible number of users to cooperative services.

\section{Services and Technological Actualization}

The TCC's degree of technological update varies according to their economic possibilities. Their autonomy, as well as - in most cases - their small size, makes them flexible enough to adopt new technologies at a relatively fast pace. Many of them are now using IP data networks, and they are beginning 
to transmit voice over IP, although traditional digital exchanges will be in service for many years. ${ }^{5}$ They are also using wireless IP for sparsely populated areas or for rural areas not reached by copper fiber networks. Moreover, FECOTEL has announced an agreement with the National Government so that associated TCCs will become shareholders of the Nahuel 2 satellite, which will be launched in $2005 .{ }^{6}$

There's a substantial difference between the cooperatives created before and after the privatization of telecommunications enterprises. Cooperatives that did not have to deal with competition, are technologically behind the times, because they have been protected by a monopolist model. New Cooperatives have entered a competitive market. Therefore, they have to incorporate top technological innovations. (Source: Interview with Eng. Bacalor, October 2004. The translation is ours).

In June 2004, the Operative Centre and Satellital teleport Cordoba was inaugurated. COLSECOR (Cooperative for the Provision of Community Broadcasting Services) and HISPASAT, the European satellite services enterprise, signed an agreement by which the Cooperative rents satellite capacity. This allows it to enter the telecommunication business by providing satellite services, Internet and public telephony. COLSECOR has thus become the first HISPASAT teleport in Argentina. (Source: LINEA N ${ }^{\circ}$ 59 July/August 2004).

If, as the Comfer (Comité Federal de Radiodifusión) authorities state, the new Broadcasting Law eliminates the barriers imposed on cooperatives supplying cable TV, then the cooperatives will offer this service, telephony and Internet for a monthly cost of 50 pesos (16 American Dollars). FECOTEL has planned investments of 400 million pesos (133 million Dollars) around the country in the next three years (between 400 and 500 Dollars for each new client).

Five TCCs are already using corDECT, India's Wireless Local Loop technology, jointly developed by Analog Services INC., Midas Communication Technologies (P) Ltd. and TeNeT group, IIT Madras. Based on the Digital Enhanced Cordless Telecommunications standard specified by the European Telecommunications Standards Institute (ETSI), corDECT provides cost-effective, simultaneous highquality voice and data connectivity in both urban and rural areas. This technology provides voice communication using $32 \mathrm{Kbps} \mathrm{ADPCM}$, and Internet connectivity at 35/70 $\mathrm{Kbps}^{7}$. In Argentina, there are two corDECT equipment suppliers, one in Buenos Aires, and another in Rosario. Soon some cooperatives from the north of Santa Fe are going to be supplied with it. (Source: interview with Mr. Mariano De Lew, Buenos Aires corDECT provider, interviewed in October 2004).

TCCs provide telephone and Internet services, by dial-up and/or broadband (ADSL) connections, as well as IP telephony, to their target populations at considerably lower prices than the large traditional firms (Telefónica and Telecom). A number of CCs also provide Wi-Fi services, as a means to provide internet access to homes and businesses. Most of them also are offering free community services, such as courses on information and communication technologies (ICTs), free access to the Internet for public schools, libraries, and public facilities (police stations, hospitals, etc.).

Moreover, some 300 electricity and telephone cooperatives have decided to join forces to provide portable phone services from 2006 onwards. ${ }^{8}$ Mobile telephony has an orientation towards low charges for local calls, and between mobile phones belonging to the same network. The potential market for the first phase is 200.000 citizens, and with an estimated potential national market of 1.100 .000 users. (Source: EN LINEA N ${ }^{\circ} .59$ July / August 2004). The negotiations around this are carried on by the largest cooperatives.

Smaller cooperatives are putting their efforts into cooperative integration in order to ensure their participation in the mobile telephone market:

In my area we could integrate four cooperatives, and therefore we can supply an excellent Internet service to our stakeholders. Moreover, we could extend this service to distant areas, such as San Pedro and Baradero. This is the result of an integrative attitude. Today the cooperative world is discussing an important project: provision of mobile telephony.

5 http://www.cicomra.org.ar/eventosycursos/Eca2003/Presentacion\%20A\%20Maccio.pdf

$6 \underline{\text { http: } / / \text { www.boonic.com/noticias/index.php?tipo }=2 \& \text { num }=848}$

7 See http://www.tenet.res.in/cordect/cordect.html visited on 15 October 2004.

8 http://www.lacapital.com.ar/2004/07/17/economia/noticia_117081.shtml 
We're going to succeed in it with integration and solidarity. We'll have the pleasure of reaching our goals by using the tool we always proclaim: solidarity. (Statements of Mr. Anibal Cardoso, Cooperativa de Servicios Públicos de Pérez Milán, Province of Buenos Aires, Education Secretary of FECOTEL, EN LINEA N 59 July / August 2004).

To date, more than 600.000 telephone lines are cooperative-managed, a number which is permanently increasing. In August 2004, the Cooperatives organized an annual event, a practice that became important for the Communications sector in 2003, and which this year exhibited the Cooperatives strengths to the public. In this Forum, FECOTEL proposed to the National Government the possibility of creating a national, cooperative-owned, telecommunications enterprise. It is still being discussed if this is to be one large cooperative, or some kind of evolution of the Federations into another kind of cooperative organization.

\section{A SEASIDE TCC: TELPIN, BACKGROUND AND CONTEXT}

In the south-east of Buenos Aires, Pinamar in Buenos Aires Province, currently one of the most fashionable seaside cities in Argentina, was born in the sandy lands known in the early nineteenth century as "Montes Grandes de Juancho" (Juancho's large woods). The 25 kilometers of dunes became urbanized in 1907. Successive urbanization projects created a thread of small tourist towns and reinforced the sand dunes with pine plantations, generating the beach name "Pinamar", signifying the combined beauty of pine woods and sea.

During the post-war years 1949 and 1953, groups of hard-working immigrant Italian families started to homestead in Pinamar. They carried with them a strong community conscience, as well as the European familiarity with cooperative organizations. The current established community was organized at that time including the founding of the local clubs and institutions such as a Primary School and a public health collaborative, later transformed into a Public Health Cooperative. In 1949, a group of neighbors created the Pinamar Water and Light Cooperative (CALP, http://www.calp.com.ar/Historia.htm ) which still serves the District with electricity, water and sanitation infrastructures, and services.

On July 1st, 1978, the "Pinamar Urban Area" (Municipio Urbano de Pinamar") was officially created. It now includes the towns of Montecarlo, Pinamar, Mar de Ostende, Ostende, Valeria del Mar, and Carilo, and has become a productive services centre linked mainly to tourist activities. According to the 2001 National Census, Pinamar has 20,666 inhabitants, a number that increases to nearly 200,000 in the summer months. Thirty-nine percent of the inhabitants are economically active: of these, 64 percent have steady jobs, while the rest are unemployed or underemployed. ${ }^{9}$ A large number of the employed inhabitants, 12 percent, work for the public sector. Employment in the private sector is in the hotel and restaurant sector, since tourist activities underpin the local economy. The literacy rate is among the highest in the country: 99.01 percent. $^{10}$

\section{The Pinamar Cooperative's Launch}

As Pinamar developed into a trendy seaside city, there was an urgent need for communication, since the town was too young, and the population was still too small to be of interest to ENTEL. Besides, the residents increased dramatically during weekends and in the summer months, and tourists needed to communicate with their families and jobs. Telpin was created by Dr. Enrique Susini, together with a group of 82 Pinamar neighbors, most of them found members of the local community, in November 14, 1962.

Telpin launched the telephone service on January 1, providing 92 lines to the same number of homes. In 1980 the traditional telephone central was replaced by a Japanese digital central, the first to be installed in the country. This innovation allowed the Cooperative to supply its shareholders with full services (wake up call, voice mail, conferences, etc.) that only a decade later, and after the privatization of the Empresa Nacional de Telecomunicaciones (ENTEL), were provided in the rest of the country. In 1982, Telpin started to send detailed phone bills to its shareholders, without additional cost. In 1984, Telpin was the first to supply International Direct Dialing (DDI). In 1993, the Cooperative again replaced the electronic central

9 Sources: 2001 National Census, and Department of Commerce, Municipality of Pinamar, 2000. 10 Source: Ministry of Interior, Secretariat of municipal Affaire, consulted in September, 2004, http://www.mininterior.gov.ar/municipales/busqueda/amplia_info.asp?ID=BUE097 
this time with an updated German central, which prepared the grounds for the further communication innovations.

I have spent some months each year in Pinamar since the 1980s. I noticed right away that the telephone worked much better than in Buenos Aires, and that it was extremely easy to get a phone line: when in Buenos Aires it took months of painstaking paperwork, in Pinamar it took only a couple of days. In those times in which it was incredibly difficult to get a phone line in Buenos Aires, and when ENTel network worked so bad, businessmen used to come to Pinamar and make all their national and international phone calls here. It was much easier and cheaper. (Source: Interview with Mrs. Amelia Ozaeta, part-time Pinamar inhabitant, former restaurant owner)

In 1998, Telpin launched Telpinet, its Internet server, including web pages hosting and maintenance. In 2004, TELPINET has 1200 subscribers. Telpin has installed 17710 lines, as well as 720 digital links with the rest of the world. ${ }^{11}$ Telpinet also provides free Internet service; the Cooperative's goal is to earn a respected place as a telecommunications services provider, without losing its community sense.

These and other services, as well as the consumption increase during the tourist season, generate benefits which return to the shareholders as important discounts (TELPIN's subscribers do not pay the subscription during the summer) and to the community in general, as new services, such as Educative Internet (Internet Educativa).

TELPIN invests its benefits in the community. In the years in which the Cooperative makes a surplus of benefits, the users don't pay any minimum charge. Local calls are unlimited, which makes easy to use the Internet: you can phone and navigate the Web for as long as you wish, and for free, except for the server. (Source: Interview with Mrs. Ozaeta).

Pinamar's Cooperative developed as extensively and innovatively as it did, not only because it served an elite public but also because some of the most outstanding Argentine entrepreneurs are part of its Council. However, there's a dynamic dialectic in this process: Pinamar also attracted upper and middle class tourists, because; besides its beautiful geography, of its competitive advantage in telecommunications: these groups needed good communications, and they could not get them elsewhere in a tourist-oriented place.

\section{Expansion policies and new market strategies}

TELPIN has gained 18,000 users, or shareholders, of diverse socio-economic groups.

Telephone lines

\begin{tabular}{|l|l|}
\hline Year & $\begin{array}{l}\text { Number of telephone } \\
\text { lines }\end{array}$ \\
\hline 2004 & $18.000 *$ \\
\hline $1999 / 2000$ & 17.710 \\
\hline $1998 / 1999$ & 15.900 \\
\hline $1997 / 1998$ & 14782 \\
\hline $1995 / 1996$ & 11.185 \\
\hline $1993 / 1994$ & $9.500 * *$ \\
\hline $1991 / 1992$ & 6.383 \\
\hline $1989 / 1990$ & 5.031 \\
\hline $1987 / 1988$ & 4.630 \\
\hline $1985 / 1986$ & 4.040 \\
\hline $1983 / 1984$ & 2.895 \\
\hline $1981 / 1982$ & 2.033 \\
\hline
\end{tabular}

Source: Pinamar's House in Buenos Aires and Cooperative TELPIN

* Market saturation: $100 \%$ of the households have telephone lines.

** The sudden increase in users is due to a decrease in costs.

11 Source: TELPIN, $\underline{\text { http://www.telpin.com.ar }}$ 
Internet users

\begin{tabular}{|l|l|l|l|l|}
\hline & 1998 & 1999 & 2000 & 2001 \\
\hline New Users & 160 & 406 & 532 & 461 \\
\hline Accumulated & 160 & 566 & 1098 & 1559 \\
\hline
\end{tabular}

In November 2004, TELPIN had 1120 broadband connections (50 of them are free, for Pinamar Schools, the public library, firemen's headquarters and other community institutions), and 3.500 other area dial-up connections ( 220 of them are free: they were granted to individuals with physical handicaps, among other users).

As mentioned earlier, in Argentina the National Telecommunications Enterprise (ENTEL) managed the whole country's telephone network, except for the areas served by cooperatives and small local enterprises. After its privatization in 1990, the Argentine State divided the telephone network's administration: it allocated the northern half of the national territory to the transnational Telecom, and the southern half to the Spanish Telefónica.

After the privatization, the evolution of the telephone market showed substantial changes. The network's digitalization increased from $13 \%$ in 1990 to $100 \%$ in 1999 . The number of lines increased by 250\%: an addition of 5 millions subscribers. In a competitive market, Telpin kept its local monopoly. This is mainly because the Cooperative had already provided its users with a service level and a loyalty-reward policy that surpassed those proposed by private enterprises. ${ }^{12}$ During the period 1990-1999, TELPIN's subscribers, far from migrating to other providers, increased 5031 to 17,710: a 352\% growth. These numbers, proportionally, would surpass by $102 \%$ the volume of new subscribers, if compared with the Telefónica and Telecom's growth rate in the rest of the country. ${ }^{13}$

\section{Evolution of business model and users profile}

Since its conception, TELPIN has been considered as a community cooperative, with strong social duties. However, the business policy is to act as efficiently as a private enterprise. Its sources of revenue are the 20.000 associates' monthly rates. It is managed by a Management Council, and supported by a General Manager and areas Managers.

Ramirez et al (2002) state that "The engagement of community "champions" is key to a successful smart community". They add: "Without partnership and teamwork a community will never succeed in becoming "Smart." However, at one time or another, someone has to take charge, step forward, and make things happen. Community champions play this role, and are key to both the instigation and the sustainability of "Smart Projects." Often an individual will be identified as the "champion", though a "team of champions" is a more reliable factor for success."

The champions' decisive role becomes evident in TELPIN. All the important initiatives were originated by a small group of enthusiasts: Eng. Santoianni, General Manager, and Mgr. Claudia Gomez Costa, Director of TELPIN Educa in 2004. TELPIN's managers receive permanent training.

A telecommunications enterprise must be really informed about the market tendencies. Training is a key issue in this matter. We must foresee where telecommunications are heading for. (...) We don't believe that cooperativism goes again entrepreneurial best practices. We're a telecommunications cooperative: we don't fund a soup kitchen, but we provide the best democratic communications services we can. (Source: Eng. Juan Santoianni, TELPIN's Manager)

12 Different Cooperatives use diverse tariff criteria, but they are generally cheaper than private telecommunications enterprises. In TELPIN's case, users pay \$12 monthly, including TVA. TELECOM, one of the two large private telecommunications enterprises, features monthly bills of $\$ 12.78$ (monthly subscription, which does not include consumption) plus $\$ 1.35$ (maintenance service) plus TVA: $\$ 14.43$. All this scales up to $\$ 17.46 \ldots$ and the user has not even yet paid for the real telephone consumption. So, commercial bills are $45.5 \%$ over TELPIN's rates, even before paying for telecommunications use. 13 Source: TELPIN data. 
The legal structure is similar to an Anonymous Society (Sociedad Anónima): each associate is a shareholder; the difference with an enterprise lies in that each associate represents a vote, independently of his or her involvement in the cooperative or the money he or she contributes. In the case that an associate uses several phone lines (as in the case of a hotel), each line represents a share; in any case, he or she is entitled to only one vote in the Cooperative.

The Cooperative has special payment plans for those users with financial difficulties. Moreover, in months when the Cooperative's balance is particularly plentiful, a discount is granted to all the users. For a monthly payment of $\$ 10$ pesos (\$3 USD) the associates receive a telephone line with unlimited local calls. This is useful for the poor, generally seasonal workers (house painters, repairmen, gardeners, domestic help) who live mostly in Ostende, for whom there are special payment facilities: they can pay 1 peso $(\$ 0.33$ USD) for a phone line, with unlimited local calls, and then make up by paying 12 pesos per months. In the winter months there are special discounts, and seasonal workers may pay 7 pesos per month, less than they would pay for bus transportation if they have to travel in the area to search for work.

TELPIN has implemented a cross subsidy for certain services. Long distance national and international calls finance local calls. The Internet also plays an important role in the Cooperative's financial sustainability: In 1994, the year in which the Internet finally arrived in Argentina, there were no Internet providers for the provinces. TELPIN has provide Internet service since 1997, at an additional cost of 30 pesos (\$10 USD) per month. That year the Cooperative bought equipment that allowed the simultaneous connection of 60 modems. They gave the users a free Internet trial. Three months later, the Internet network had reached saturation level, and TELPIN had to buy additional equipment. The cooperative's scheme differed from other Internet Service Providers: while usually ISPs use a modem for each 20 real users, charging for each minute of connection, TELPIN had a modem for each 5 users, charging lower prices for full connections, and consequently, achieving a critical mass of users. In 1998, counting the amortization of the acquired equipment, the operation showed a net positive return. From then on, the Cooperative has not stopped investing in Internet services.

\section{The community's role}

Even if all the households in Pinamar are TELPIN's shareholders, their participation is not direct: the cooperative organizes an annual assembly in which the authorities are elected. The list is composed of individuals considered representative of the whole community, even if most of its members are outstanding entrepreneurs.

The community owns and finances the Cooperative, now one of the most important businesses in Pinamar. TELPIN's investments in technology have the community's support. Community members also have control over the Cooperative, through access to their monthly balances and periodic monitoring. The community's loyalty to their cooperative has been a key factor in the Cooperative's sustainability.

Our balance sheets are done each month. Our consumption measurers are updated daily. We can predict the year's profits and estimate which discounts that our associates will enjoy for the next two months. But we don't stop investing in our Coop, because it's our way to grow, and to become technologically innovative. We don't always make the best financial investments in the long run, but it's always the best organizational investment, because it results in free publicity, done by our own users. For example, our Internet users boast: 'I can be connected the whole day through, and I pay only $\$ 30$ '. In 1997 , that was an excellent price in the world, because Internet users were paying 25 or 30 US Dollars, but they had to pay for the telephone consumption besides. Any Internet user in the World paid then 50 or 60 US Dollars a month. (Source: Eng. Juan Santoianni, TELPIN's Manager in 2004).

Eng. Santoianni likes to tell an anecdote to illustrate the users' loyalty to TELPIN: In 1999, Telefónica asked the National Communications Commission (Comisión Nacional de Comunicaciones, CNC) to free up Pinamar's area for long distance service subscription. Telefónica introduced seven vans, with four employees each, to rake the area, calling each house and apartment to sign-up the inhabitants for Telefónica's long distance services. They worked for two weeks, presenting what was in fact a deceptive statement, that the cooperative could not offer long distance services. They managed to get 15 contracts. When the users asked TELPIN to terminate their contracts, explaining that they wanted to switch to 
Telefónica, because "TELPIN cannot supply us with long distance services," TELPIN explained to them the mistake. Fourteen of the users returned to TELPIN. The experience proved the population's commitment to TELPIN and its social involvement.

TELPIN has offered access to the Internet since late 1998. The Cooperative's associates can have a second telephone line for a symbolic cost: of one peso, about $\$ 0.33$ USD. Since local dial-tone is free, the only cost they must pay to have an Internet connection is to the ISP. In October 2004, TELPIN had 20000 subscribers to its ISP services, of which 50 (mainly schools) enjoy a free subscription. Users pay 30 pesos ( $\$ 10$ USD) for full Internet. If they subscribe to the broadband service 256, the cost is $\$ 58.90+$ TVA (value added tax of around \$20 USD), and the broadband service 512: \$78.90 + TVA (Around \$30 USD). The hosting of websites costs \$20+TVA. TELPIN has implemented a public telecenter with 8 computers in Pinamar Popular Library, with free public access to the Internet. It has also equipped with computers and free connection the local Voluntary Firemen's' quarters. At present, all of Pinamar schools, 5,000 students and more than 17,000 citizens benefit from full free Internet connections.

\section{EDUCATIONAL INTERNET}

TELPIN's most outstanding action is Internet educativa (Educational Internet, www.telpin.com.ar iitelpineduca), a unique experience in Latin America. It was launched in early 1999. TELPIN Educa's Technical Director is Eng. Juan Santoianni, and its Pedagogic Director is Mgr. Claudia Gómez Costa. TELPIN provides Internet connection to all the District schools: Kindergartens, primary and secondary schools, as well as technical schools, both public and private. All the educational institutions are connected to the Internet and to an Educational Electronic Network.

TELPIN supplies computers, connections, server, and technical services. It also provides training for teachers, a key element of Educational Internet. Teachers were given the opportunity to deepen their knowledge of Informatics resources, increase their use in educational practices, and learn how to build websites for their respective institutions (http://www.telpin.com.ar/interneteducativa).

TELPIN's courses do not focus on the traditional informatics teaching (Word, Excel, etc.) but on the tools that allow both teachers and students to "appropriate" the new cyber territory, circulate in it, integrate virtual networks, and incorporate their own content (e-mail, html, etc.). Educators are equipped with the basic tools that allow them to acquire the cultural capital they need in the Information Society, and in turn, make their own contributions to the new society.

This is the only case in Latin America with these characteristics, and with teachers that have been continually trained for six years. They did not know how to turn on a computer, and they are now working in collaborative networks, and generating marvelous projects. (...) Now several provinces and cities in the country have invited us to study how to implement TELPIN Educa there. (Source: Mgr. Claudia Gomez Costa, Director of TELPIN Educa in 2004).

At present, all of Pinamar District Schools have their own websites, built by their teachers and professors. In Pinamar, five kindergartens, eight primary schools, two Secondary schools, one physical Education Center, three education management institutions, and sixteen community organizations ${ }^{14}$, are integrated into the Internet Educativa. All of them are supplied with computers, Internet connections, server and technical services.

In 2002, TELPIN extended Internet Educativa to the nearby General Madariaga District, and in 2001, to the city of Trenque Lauquen, in the La Pampa Province. The National Ministry of Education decided to implement the Course: "Appropriate Use of the Internet in Education" for 1000 Trenque Lauquen teachers. In August 2001, the Course was chosen by the Foundation Equity (Fundación Equidad, http://www.equidad.org/) to be implemented in the Province of Neuquén, Patagonia, within the Program of Schools Informatization (Programa de Informatización Escolar) funded by the oil company Repsol -YPF. The course trained a total of 46 "teacher-trainers" in 19 schools in Neuquén. Between 2001 and 2002 the experience was extended to the Patagonic Provinces of Santa Cruz and Chubut. Until October 2004, more

14 See http://www.telpin.com.ar/InternetEducativa/LP/SEP.htm, consulted in September 2004. In this page, there are links to the educational institutions websites. 
than 2000 teachers and professors in Buenos Aires, Neuquén, Chubut and Santa Cruz have been trained to use ICTs for educative purposes.

Claudia Gomez Costa attributes the success of TELPIN Educa to the original idea, the decision that the initiative should be sustainable for a long time, the team, and mainly, "the human factor":

All of my professors were trained as teachers, and they have years of experience teaching in schools. All of them specialize in ICT for education, in different areas: art, History, Geography, a special professor for the handicapped... I would say that the human factor and appropriate training are the key factors for success. (Source: Mgr. Claudia Gomez Costa, Director of TELPIN Educa in 2004).

\section{ANALYSIS AND CONCLUSIONS}

We have found support for our main hypothesis: Telecommunications Community Cooperatives are a line of attack for Civil Society organizations to set up communities for their new roles. In this way Civil Society can begin to proactively partake in the building of a new economy, helped by fast and low-cost access to Internet connections, education on ICT uses, capacities to implement the communities' ownership of ICT infrastructures, alertness to identifying the opportunities existing in the emerging information Society, and towards the effective use of information and communication technologies.

Telecommunications Community Cooperatives are realizing a social role unparalleled in Latin American countries ${ }^{15}$, not only as services providers, but also as employment generators:

1. TCCs are the only telecommunications providers in Argentina with entirely Argentine capital (local communities' capital). The initial TCCs capital, as with any cooperative's opening capital, comes from the associates contributions. They also supply a monthly quota to support the Cooperative, which varies according to the range of circumstances.

2. They are social centers, since they provide social content, and enhance community activities.

3. They offer employment for qualified and non-qualified labor.

4. Many of them provide education and training in the diverse uses of ICTs.

5. The successive economic crises suffered by Argentina were not used as excuses to fire employees.

6. They are solidarity-economy enterprises; therefore, their economic surplus is invested in other community projects, creating a multiplier effect in the local and regional economy.

7. They are providers of fast and low-cost access to Internet connection.

8. Local capital does not migrate to foreign countries; on the contrary, they encourage local economic development, and they improve their communities' quality of life.

9. They are agents of democratization and social appropriation of telecommunications infrastructures.

Within these cooperatives, the case of TELPIN is paradigmatic: it is considered the most successful and innovative telecommunications cooperative in the country. However, its formation had some exception circumstances, not easily replicable in other areas: among its initial associates there were some of the most successful entrepreneurs in the region; a local enterprise, Pinamar, S.A., contributed generously to its financial beginnings; and the local population, being linked to tourist activities, demanded communications with the world, promptly understood and supported the initiative. At its origins, TELPIN had-and still has - extraordinary leadership form local and national businessmen, who contributed their expertise, as well as their contacts.

However, these were not the only factors contributing to its success: The main factor is the existence of passionate, lucid champions willing to put their expertise and their knowledge to make TELPIN the most innovative cooperative in the country; the management, simultaneously community and enterprise-oriented, together with the constant updating and training of the management staff; the willingness to venture into technological and organizational innovations, and most of all, the quality and responsibility of the human resources.

15 Bolivia is an exception: The Federation of Bolivian Telephone Cooperatives, FECOTEL, was launched in 1987 in Santa Cruz de la Sierra, http://www.comteco.com.bo/cooperativa/FecEstat.doc 
TELPIN also has cutting edge technology, as well as better and less expensive services than its private competitors. It also supplies superior customer services. These elements earned it their users' loyalty and commitment. The benefits to the community derived from TELPIN's actions are evident: full telephone coverage at lower costs than the traditional private enterprises', Internet at affordable prices, full free telecommunication services for the community's institutions, innovative technology, and generation of local employment. The community owns and finances the Cooperative, and controls their finances and investments through their monthly balances and period monitoring. TELPIN's investments in technology have full community support. The community's commitment to their cooperative has been a key reason for the Cooperative's sustainability.

Moreover, the characteristic that makes TELPIN a unique case in Latin America is TELPIN Educa, the educational innovation for the Information Society that has achieved successful results and remarkable social and cultural impacts on the community, not only in Pinamar, but also in other regions in the country.

The innovations involved in the general TELPIN initiative were mostly managerial and technological. From the managerial point of view, the fact of using the most expensive services, such as international telephone calls, to subsidize the most popular ones, such as local calls, the concept of managing the cooperative as an enterprise, while keeping its social values and the quality of the human resources involved ensured its sustainability and continuity. From the technological point of view, the Cooperative was a pioneer from the beginning, introducing technologies and services much earlier than the large, private telecommunications enterprises.

\section{Lessons learned:}

Telecommunications Community Cooperatives are potential tools to democratize communications, since the community becomes the owner of its communications infrastructure.

Commitment to their communities is fundamental to the success of cooperatives: this implies continuous efforts to provide cutting edge technology, managerial efficiency, better and less expensive services than its private competitors, and superior customer services.

Community engagement is a key factor for the success of community cooperatives.

In order to become replicable in other Argentina regions, or in developing countries, TCCs must count on: appropriatet legislation that allows them to compete with private providers; a favorable fiscal status; a local community capable of raising funds, either with their own financial participation, or by obtaining credits from banks or international organizations; and a talented, preferably professional management, responsibly open to managerial and technological innovations.

The launching of TCCs implies that community members must make serious financial efforts, given that the main investment sources come from their associates or shareholders-not only the potential users, but mainly local enterprises--and from National or provincial Banks through soft loans. For this reason, low-income communities may have difficulties in implementing TCCs, unless they can negotiate investments from national Banks or international organizations.

The case of TELPIN, as well as the history of the cooperatives movement in Argentina, shows that the involvement of local champions is essential for the success of TCC initiatives, not only for the first stages, but also-and mainly--for long-term sustainability.

Not only is there safety in numbers, but also negotiating in capacity cooperatives achieve better results, either when negotiating with governments or with private enterprises, if they can integrate networks or Federations.

Capacity building is essential for long-term accomplishment: constant training of the cooperatives' responsible members, either technicians or managers, is a key factor for success.

Communities also need training to obtain the benefits of the Information Society: TCCs have an irreplaceable role to play as community educators.

TCCs can lead to ancillary community developments: a community which is communicating and trained to use Information Society tools is also able to develop micro enterprises or SMES using ICT, e.g. 
the development of tourist and educational websites, online publicity for tourism, or the multiplicity of cybercafés in Pinamar.

TCCs can lead to related local entrepreneurial developments, such as software production, technological goods and services, training in managerial abilities, and others. 


\section{References}

Bridges.org (2001), “Comparison of E-Readiness Assessment Models, Final draft, v. 2.13, 14 March 2001, downloaded from: http://www.bridges.org/ereadiness/tools.html

Castells, M. (2000) “Is the New Economy Socially Sustainable?” Downloaded from: http://www.ul.ie/ icse2000/castellsabstract.html

Castells, M. (2000). Manuel Castells Keynote Summary, http://www.ul.ie/ icse2000/wow/issue2/manuel castell keynote.htm

FECOTEL (n.d.). TESTIMONIO DEL ESTATUTO SOCIAL REFORMADO DE LA FEDERACION DE COOPERATIVAS DE TELECOMUNICACIONES DE LA REPUBLICA ARGENTINA LTDA. Capitulo I. denominación, domicilio, duración y objeto. http://www.fecoteldatos.com.ar/estatuto.doc

Finquelievich, S. (2003). ICTs and Poverty Reduction in Latin America and the Caribbean, ICA - IDRC.

Finquelievich, S. (2004). LAGO MARTÍNEZ, Silvia; JARA, Alejandra; Vercelli, Ariel. TIC, desarrollo y reducción de la pobreza: Políticas y propuestas. [online]. Buenos Aires: Instituto de Investigaciones Gino Germani, Facultad de Ciencias Sociales, Universidad de Buenos Aires, 2004. (IIGG Documentos de Trabajo, $N^{\circ} 37$ ). Downloaded from http://www.iigg.fsoc.uba.ar/docs/dt/dt37.pdf

Finquelievich, S. (2004). La sociedad civil en la economía del conocimiento: TICs y desarrollo socioeconómico. [online]. Buenos Aires: Instituto de Investigaciones Gino Germani, Facultad de Ciencias Sociales, Universidad de Buenos Aires, 2004. (IIGG Documentos de Trabajo, No 40). $<$ http://www.iigg.fsoc.uba.ar/docs/dt/dt40.pdf $>$

Gurstei, M. (2003). Community Innovation and Community Informatics Building National Innovation Capability from the Bottom Up, December 2003. Downloaded from http://www.ciresearch.net/Innovation.doc

Kelly, K. (1997, September). New Rules for the New Economy, WIRED, Issue 5.09 downloaded from http://www.wired.com/wired/5.09/newrules.html

Lanvin, B. (2001). The Global Information Technology Report 2001-2002: Readiness for the Networked World, Center for International Development at Harvard University, Downloaded from http://www.cid.harvard.edu/cr/gitrr 030202.html.

Obendorf, Tricia (2000): Manuel Castells Leads Keynoters, in Window of the World, Issue 2, http://www.ul.ie/ icse2000/wow/issue2/manuel_castell_keynote.htm

Ricardo Ramírez, Helen Aitkin, Galin Kora \& Don Richardson (2002): Community engagement, performance measurement and sustainability: Experiences from Canadian community based networks, accessed April 27, 2005 from http://www.is.njit.edu/vci/iwcil/ramirez.doc.

Stiglitz, Joseph (2003): "Los felices 90”, Taurus, Buenos Aires.

Tapper, H. (n.d.). Understanding the Information Society Paradigm. Accessed 2004, http://www.valt.helsinki.fi/comm/argo/argonet9/TAPPER.HTM 